\title{
STUDY OF SPATIAL PROBLEMS OF DYNAMIC STABILITY OF REINFORCED CONCRETE FRAMES
}

\author{
${ }^{1}$ Fomin V.M., Doctor of Technical Sciences, Associate Professor, \\ Fomin@ogasa.org.ua, ORCID: 0000-0003-4814-6415 \\ ${ }^{1}$ Fomina I.P., Senior Lecturer, \\ Fomina@ogasa.org.ua, ORCID: 0000-0001-7366-1537 \\ ${ }^{1}$ Odessa State Academy of Civil Engineering and Architecture \\ 4, Didrikhson str., Odessa, 65029, Ukraine
}

\begin{abstract}
The article proposes a method for constructing areas of dynamic instability of reinforced concrete frames in the space of parameters (frequency and amplitude) of seismic and operational dynamic impacts that cause the appearance of longitudinal forces in the bars of structures, which periodically change in time and lead to an unlimited increase in amplitudes of transverse vibrations when the values of these parameters are in the areas of instability. The proposed method is demonstrated by a specific example, which considers the spatial problem of dynamic stability of a $\Pi$-shaped frame with two concentrated masses located on it, which are under the action of vertical periodic forces. These forces create periodic longitudinal forces in the vertical rods of the frame. Areas of dynamic instability of the frame are constructed.

From the point of view of human activity, fluctuations can be both beneficial and harmful. We can observe vibrations of various buildings, structures, bridges, which cause additional stresses and deformations of these structures, have a harmful effect on their safe functioning. Too intense fluctuations lead to serious consequences. This leads to the destruction of individual elements of the structure and, as a result, to accidents. The most destructive effect of vibrations is observed during earthquakes and explosions. The study of vibrations is of great practical importance. This avoids the unwanted effects of fluctuations by limiting their level. Only on the basis of a deep study of various types of vibrations can important practical problems of the dynamics of structures be solved. Solving dynamics problems is a complex problem. In contrast to static calculation, when studying oscillations, one has to take into account an additional factor - time.

The dynamic design of structures provides them with bearing capacity under the combined action of static and dynamic loads. A construction will be considered as a system with an infinite number of elementary masses distributed over it with an infinitely large number of dynamic degrees of freedom.
\end{abstract}

Keywords: reinforced concrete frames, dynamic instability, areas of instability.

Introduction. The first work in the field of dynamic stability of structures was published by N.M. Belyaev in 1924. It posed and solved the problem of dynamic stability of a rod hinged at the ends, i.e, the conditions for the appearance and oscillation of transverse oscillations of the rod under the action of periodic longitudinal force were studied. It was shown that the values of the frequency and amplitude of oscillations of the longitudinal force, in which there is an unlimited increase in the amplitude of transverse oscillations of the rod, form continuous regions in the space of these parameters, called instability regions. In 1935, N.M. Krylov and M.M. Bogolyubov, and in 1940 E. Mettler [1] continued the research of N.M. Belyaev, investigating the problem of dynamic stability of the rod with arbitrary fixing of its ends. In the book V.N. Chelomey [2], published in 1939, considered the problems of dynamic stability for rods of variable cross-section, for rods with initial deflection, as well as for multi - beam rods. In 1953-1956, V.V. Bolotin published a number of works on the dynamic stability of rods, beams and frames [3].

It should be noted that in these works flat problems of dynamic stability were investigated. In the work of N.A. Nikolaenko and Yu.P. Nazarov [4], published in 1970, solved the spatial problem of dynamic stability of structures. The model of the structure in the form of a system of absolutely

Bulletin of Odessa State Academy of Civil Engineering and Architecture, 2021, no. 85, page 62-70 
rigid bodies (intermediate floors) connected by a system of geometrically nonlinear connections modeling the columns of the structure was proposed. However, for long-term designs, this model is not entirely accurate.

Analysis of recent research and publications. Many works consider flat problems of dynamic stability of frames. N.A. Nikolaenko and Yu.P. Nazarov and their students studied the spatial problem of dynamic stability of buildings using a model of construction in the form of a system of rigid bodies (floors), connected by elastic rods (columns). However, for long-term structures, this model is not entirely correct due to the fact that the floors can receive significant deformations in the horizontal plane. To study the spatial problem of dynamic stability of structures in this paper proposes the use of a model of a structure in the form of a mechanical system consisting of a weightless frame structure with a system of concentrated masses located in its nodes. In addition, the work uses a method modified by the author V.V. Bolotin, proposed to solve flat problems of dynamic stability of frames. Instead of the method of deformation used by V.V. Bolotin to construct analytical expressions of deflections of frame rods, in the modified method the numerical-analytical method of boundary elements is used.

Purpose and objectives. The aim of this work is to study the spatial problem of dynamic stability of structures using a model of a structure in the form of a mechanical system consisting of a weightless frame and concentrated masses located in its nodes (note that this type of model is used in normative calculation of structures for seismic effects).

The main task is to develop a method that would allow studying the dynamic stability of spatial multi - story multi - span frame structures under seismic and dynamic operational influences.

Materials and methods of research. The paper uses a modified method V.V. Bolotin, proposed in [3] to solve flat problems of dynamic stability of frames. In this case, instead of the method of deformation used by V.V. Bolotin to construct analytical expressions of deflections of frame rods, the numerical-analytical method of boundary elements is used $[5,6]$.

Research results. Let us number the rods of the frame and enter on each of the rods a local rectangular coordinate system $x_{k}, y_{k}, z_{k},\left(k-\operatorname{rod}\right.$ number, axis $x_{k}$ is directed along the axis of the rod). In addition, we introduce the global abscissa $s$ of the points of the frame as follows: $s=x_{1}$ for the points of the axis of the first rod, $s=\sum_{\mathrm{j}=1}^{k-1} l_{j}+x_{k}$ for points of the axis of the rod with the number $k>1$ ( $l_{j}-$ the length of the $j-{ }^{\text {th }}$ rod). We will look for dynamic deflections of rods of a frame in the following form:

$$
\boldsymbol{v}(s, t)=\sum_{i=1}^{n} w_{i}(t) \boldsymbol{\Phi}_{i}(s)
$$

$n$ - the number of degrees of freedom of the above-mentioned mechanical system. Here, in contrast to [5] $\boldsymbol{v}(s, t)$ is not a scalar function, but a vector:

$$
\boldsymbol{v}(s, t)=\left[\begin{array}{l}
v_{y}(s, t) \\
v_{z}(s, t) \\
\Theta(s, t)
\end{array}\right],
$$

( $v_{y}-$ deflection of the rod at a point with abscissa $s$ in the direction of the $y$-axis of the local coordinate system, $v_{z}$ - in the $z$ - axis direction of this system, $\Theta$ - the angle of rotation of the cross section $), w_{i}(t)$ are scalar functions, $\boldsymbol{\Phi}_{i}(s)$ are three - dimensional vector functions:

$$
\boldsymbol{\Phi}_{i}(s)=\left[\begin{array}{c}
\Phi_{i, 1}(s) \\
\Phi_{i, 2}(s) \\
\Phi_{i, 3}(s)
\end{array}\right] .
$$

In [3] it is stated that as $\boldsymbol{\Phi}_{i}(s)(i=1,2, . ., n)$ we can take functions with the help of linear combinations of which we can approximate the forms of free vibrations of the structure. In particular, 
you can use the functions of deflections of the frame from the action of forces $\boldsymbol{F}_{\boldsymbol{i}}\left(F_{i}==1 \kappa H, i=1\right.$, $2, \ldots n)$, applied to concentrated masses. Considering $w_{i}(t)$ as generalized coordinates, we compose the Lagrange equation for this problem:

$$
\frac{d}{d t}\left(\frac{\partial T}{\partial w_{i}}\right)+\frac{\partial}{\partial w_{i}}(U-T)=Q_{i} \quad(i=1,2, \ldots, n),
$$

Where: $T$ i $U$ - kinetic and potential energy of the frame with a system of concentrated masses located on it, $Q_{i}-$ generalized forces.

The kinetic energy of the system is equal to the sum of the kinetic energies of the concentrated masses:

$\left.T(t)=\frac{1}{2} \sum_{j=1}^{r} m_{j}\left[v_{y}^{2}\left(s_{j}, t\right)\right)+v_{z}^{2}\left(s_{j}, t\right)\right]$,

$r$ - the number of concentrated masses). Taking into account formulas (1) - (3) we obtain:

$$
\frac{\partial T}{\partial w_{i}}=\sum_{j=1}^{r} m_{j}\left[\Phi_{i, 1}\left(s_{j}\right) \sum_{k=1}^{n} w_{k}(t) \Phi_{k, 1}\left(s_{j}\right)+\Phi_{i, 2}\left(s_{j}\right) \sum_{k=1}^{n} w_{k}(t) \Phi_{k, 2}\left(s_{j}\right)\right](i=1,2, \ldots, n) .
$$

Changing the order of summation by $j$ and $k$, we obtain:

$$
\frac{\partial T}{\partial w_{i}}=\sum_{k=1}^{n} f_{i k} w_{k}(t)
$$

where:

$$
f_{i k}=\sum_{j=1}^{r} m_{j}\left[\Phi_{i, 1}\left(s_{j}\right) \Phi_{k, 1}\left(s_{j}\right)+\Phi_{i, 2}\left(s_{j}\right) \Phi_{k, 2}\left(s_{j}\right)\right] .
$$

The potential energy of each of the rods of the frame consists of the potential bending energies of the rod in the planes $x y$ and $x z$ of the local coordinate system and the potential energy of rotation around the axis of the rod. Therefore, the potential energy of the frame is determined from the ratio:

$$
U(t)=\frac{1}{2}\left\{\int_{0}^{L} E(s) J_{z}(s)\left[v_{y}^{\prime \prime}(s, t)\right]^{2} d s+\int_{0}^{L} E(s) J_{y}(s)\left[v_{z}^{\prime \prime}(s, t)\right]^{2} d s+\int_{0}^{L} G(s) J_{p}(s)\left[\Theta^{\prime}(s, t)\right]^{2} d s\right\} .
$$

Here the bar means a derivative by $s, J_{p}(s)$ - the polar moment of inertia of the cross section relative to the center of intersection, $E(s), G(s)$ - modulus of elasticity and shear of the material of the frame rods, $L-$ is the total length of the frame rods. After substituting the relationship (1) in (9) and differentiation by $w_{i}$ we receive:

$$
\frac{\partial U}{\partial w_{i}}=\sum_{k=1}^{n} r_{i, k} w_{k}(t)
$$

where:

$$
r_{i, k}=\int_{0}^{L} E(s) J_{z}(s) \Phi_{\mathrm{i}, 1}^{\prime \prime}(s) \Phi_{k, 1}^{\prime \prime}(s) d s+\int_{0}^{L} E(s) J_{y}(s) \Phi_{\mathrm{i}, 2}^{\prime \prime}(s) \Phi_{k, 2}^{\prime \prime}(s) d s+\int_{0}^{L} G(s) J_{p}(s) \Phi_{\mathrm{i}, 3}^{\prime}(s) \Phi_{k, 3}^{\prime}(s) d s .
$$

The work of the external distributed transverse load is determined as follows:

$$
V=\int_{0}^{L}\left[q_{y}(s, t) v_{y}(s, t)+q_{z}(s, t) v_{z}(s, t)\right] d s,
$$

where: $q_{y}, q_{z}, v_{y} v_{z}-$ components of loads and deflections of rods in the corresponding local coordinate systems.

Generalized forces can be found from the relations: $Q_{i}=\frac{\partial V}{\partial w_{i}} \quad(i=1,2, \ldots, n)$.

From (1) it follows that:

$$
Q_{i}(t)=\int_{0}^{L}\left[q_{y}(s, t) \Phi_{i, 1}(s)+q_{z}(s, t) \Phi_{i, 2}(s)\right] d s(i=1,2, \ldots, n) .
$$


Making in (12) integration by parts, we obtain:

$Q_{i}(t)=-\int_{0}^{L}\left[Q_{y}(s, t) \frac{\partial \Phi_{i, 1}(s)}{\partial s}+Q_{z}(s, t) \frac{\partial \Phi_{i, 2}(s)}{\partial s}\right] d s(i=1,2, \ldots, n)$.

Here $Q_{y}(s, t)$ and $Q_{z}(s, t)$ - components of the transverse force in the cross sections of the rods.

We limit ourselves by solving problems of dynamic stability under the action of vertical variable forces applied to concentrated masses. The influence of the longitudinal forces that arise in the rods of the frame on their bending deformation is taken into account by the ratio [3]:

$Q_{y}(s, t)=-N(s, t) v_{y}^{\prime}(s), Q_{z}(s, t)=-N(s, t) v_{z}^{\prime}(s)$. by time:

We consider the case when the forces acting on concentrated masses change synchronously

$$
P_{j}(t)=(\alpha+\beta \cos \psi t) P_{0, j}(j=1,2, \ldots, r),
$$

$\alpha$ and $\beta$-positive scalar parameters.

It is assumed that $\alpha$ is less than the critical value, i. e. that the structure under the action of static forces $\alpha P_{0, j}(j=1,2, \ldots, r)$ are less than critical value, i. e. it is in a position of stable equilibrium. From (14) it follows that for the longitudinal forces in the rods of the frame there is the following relationship:

$$
N(s, t)=(\alpha+\beta \cos \Theta t) N_{0}(s),
$$

where $N_{0}(s)$ - longitudinal forces in the rods of the frame caused by forces $P_{0, j}(j=1,2, \ldots, r)$.

From (13) and (15) it follows:

$$
Q_{i}(t)=(\alpha+\beta \cos \psi t) \int_{0}^{L} N_{0}(s)\left[v_{y}^{\prime}(s) \Phi_{i, 1}^{\prime}(s)+v_{z}^{\prime}(s) \Phi_{i, 2}^{\prime}(s)\right] d s(i=1,2, \ldots, n) .
$$

Using the expansion (1), we obtain:

$$
\begin{aligned}
& Q_{i}(t)=(\alpha+\beta \cos \psi t) \sum_{k=1}^{n} s_{i k} w_{k}(t) \quad(i=1,2, \ldots, n), \\
& s_{i k}=\int_{0}^{L} N_{0}(s)\left[\Phi_{i, 1}^{\prime}(s) \Phi_{k, 1}^{\prime}(s)+\Phi_{i, 2}^{\prime}(s) \Phi_{k, 2}^{\prime}(s)\right] d s(i, k=1,2, \ldots, n) .
\end{aligned}
$$

Substitution of (7), (10) and (16) into the Lagrange equation (4) leads to a system of differential equations:

$$
\sum_{k=1}^{n} f_{i k} \ddot{w}_{k}(t)+\sum_{k=1}^{n}\left[r_{i k}-(\alpha+\beta \cos \psi t) s_{i k}\right] w_{k}(t)=0(i=1,2, \ldots, n),
$$

which in matrix form is written as follows:

$$
\boldsymbol{F} \ddot{\boldsymbol{w}}+[\boldsymbol{R}-(\alpha+\beta \cos \psi t) \boldsymbol{S}] \boldsymbol{w}=0 .
$$

If $\beta=0$, i.e. when forces $P_{j}(j=1,2, \ldots, r)$ are constant, the system of equations (18) in this case:

$\boldsymbol{F} \ddot{\boldsymbol{w}}+[\boldsymbol{R}-\alpha \boldsymbol{S}] \boldsymbol{w}=0$,

determines the free vibrations of the frame, the rods of which are loaded with longitudinal constant forces. Substitution $\boldsymbol{w}=\boldsymbol{W} \sin \Omega t$ into (19) allows us to construct the equation of frequencies of free oscillations of such a frame:

$$
\operatorname{det}\left(\boldsymbol{R}-\alpha \boldsymbol{S}-\Omega^{2} \boldsymbol{F}\right)=0 .
$$

To study the dynamic stability of the structure, it is necessary to use a system of differential equations (18) with coefficients that periodically depend on time. By multiplying this system by $\boldsymbol{R}^{-1}$, we bring it to the following form:

$$
\boldsymbol{C} \ddot{w}+[\boldsymbol{E}-(\alpha+\beta \cos \psi t) \boldsymbol{A}] \boldsymbol{w}=0 \text {. }
$$

Here $\boldsymbol{C}=\boldsymbol{R}^{-1} \boldsymbol{F}, \boldsymbol{A}=\boldsymbol{R}^{-1} \boldsymbol{S}, \boldsymbol{E}-$ is the unit matrix. The boundaries of the main areas of instability in the first approximation are determined from equality [5]: 


$$
\operatorname{det}\left[\boldsymbol{E}-\left(\alpha \pm \frac{1}{2} \beta\right) \boldsymbol{A}-\frac{1}{4} \psi^{2} \boldsymbol{C}\right]=0 \text {. }
$$

Note that in [5] the main areas of instability are areas in the plane of parameters $\beta, \psi$ (at a fixed value $\alpha$ ), boundaries of which at $\beta=0$ converge at points $\psi_{k}=2 \Omega_{k}\left(\Omega_{k}\right.$ - one of the frequencies of free vibrations of the frame loaded by constant longitudinal forces. In (22) the plus sign corresponds to the lower boundary of the area, and the minus sign - to the lower one.

We will demonstrate the proposed technique on a specific example.

Example. The spatial problem of dynamic stability of a $\Pi$-shaped frame with two concentrated masses $M_{1}$ and $M_{2}$ under the action of two vertical periodic forces $P_{1}(t)$ and $P_{2}(t)$ is considered (Fig. 1).

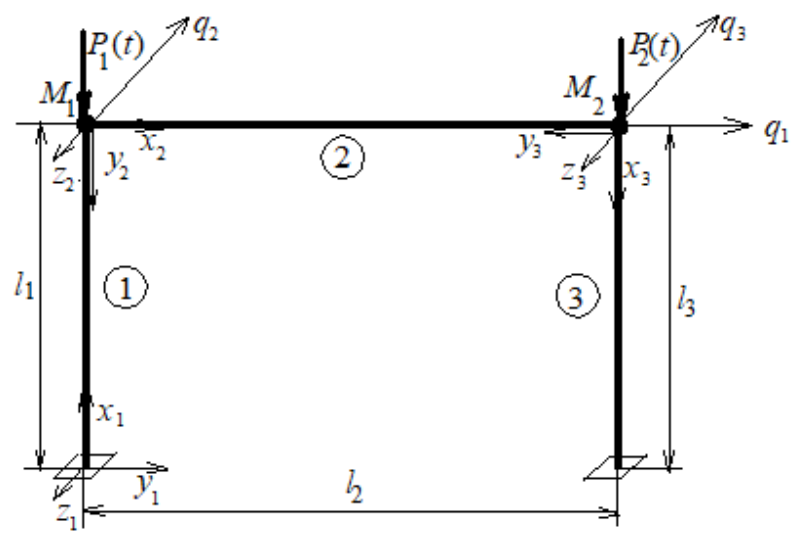

Fig.1. П-shaped reinforced concrete frame

The drawing shows the axes of the local coordinate systems $x_{k}, y_{k}, z_{k}(k=1,2,3)$ on each of the frame rods. Material point system $M_{1}, M_{2}$ has three degrees of freedom. They correspond to the axis of the system of generalized coordinates $\mathrm{q}_{1}, \mathrm{q}_{2}, \mathrm{q}_{3}$. Design parameters: $l_{1}=l_{3}=6 \mathrm{M}, l_{2}=10 \mathrm{~m}$. Masses of material points: $\mathrm{m}_{1}=\mathrm{m}_{2}=50$ ton. Dimensions of cross section bars of elasticity of reinforced concrete (averaged) $\mathrm{E}=2,7 \cdot 10^{4} \mathrm{MPa}$, offset module $G=1,125 \cdot 10^{4} \mathrm{MPa}$ [8].

To build functions $\mathbf{F}_{i}(s)(i=1,2,3)$ we use the boundary element method [5]. Apply to the point $M_{1}$ force $\boldsymbol{F}_{\mathbf{1}}\left(F_{1}=1 \kappa N\right)$ in the direction of the axis $q_{1}$. In Fig. 2. schematically depicts the deformed state of the frame caused by the influence of force $\boldsymbol{F}_{1}$.

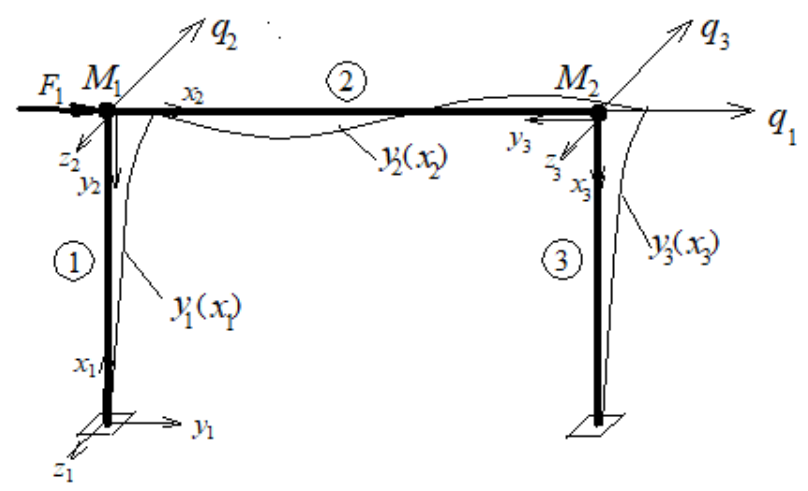

Fig. 2. Deformed state of the frame under the action of force $\boldsymbol{F}_{1}$

Analytic function expressions $y_{1}\left(x_{1}\right), y_{2}\left(x_{2}\right), y_{3}\left(x_{3}\right)$ look like this:

$$
\begin{aligned}
& y_{1}\left(x_{1}\right)=4.703115610^{-5} x_{1}-4.572474 \cdot 10^{-6} x_{1}^{3}, \\
& y_{2}\left(x_{2}\right)=7.0546737 \cdot 10^{-5} x_{2}-2.116402 \cdot 10^{-5} x_{2}^{2}+1.410935 \cdot 10^{-6} x_{2}^{3}, \\
& y_{3}\left(x_{3}\right)=-7.054674 \cdot 10^{-4}+7.054674 \cdot 10^{-5} x_{3}+3.527337 \cdot 10^{-5} x_{3}^{2}-4.572474 \cdot 10^{-6} x_{3}^{3} .
\end{aligned}
$$

Note that $z_{i}\left(x_{i}\right)=0, \Theta_{i}\left(x_{i}\right)=0(i=1,2,3)$. Thus, the components of the function are presented as follows: 
$\mathrm{F}_{1,1}(s)=y_{1}(s)$ at $s \leq l_{1}$,

$\mathrm{F}_{1,1}(s)=y_{2}\left(s-l_{1}\right)$ at $l_{1}<s \leq l_{1}+l_{2}$

$\mathrm{F}_{1,1}(s)=y_{3}\left(s-l_{1}-l_{2}\right)$ at $s>l_{1}+l_{2}$,

$\mathrm{F}_{1,2}(s)=\mathrm{F}_{1,3}(s)=0$ at all $s$.

We apply to the point $M_{1}$ force $\left(F_{2}=1 \kappa N\right)$ in the direction of the axis $q_{2}$. Fig. 3 shows the deformed state of the frame caused by this force.

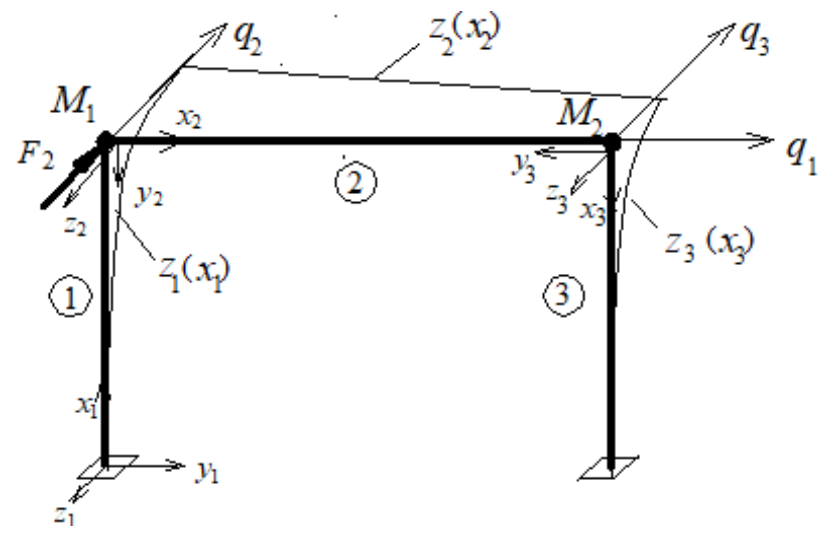

Fig. 3. Deformed state of the frame under the action of force $\boldsymbol{F}_{2}$

Analytical expressions of functions $z_{i}\left(x_{i}\right), \psi_{i}\left(x_{i}\right)(i=1,2,3)$ have the following form:

$$
\begin{aligned}
& z_{1}\left(x_{1}\right)=-1.26177228 \cdot 10^{-4} \cdot x_{1}^{2}+8.500325 \cdot 10^{-6} \cdot x_{1}^{3}, \Theta_{1}\left(x_{1}\right)=2.320639 \cdot 10^{-5} x_{1}, \\
& z_{2}\left(x_{2}\right)=-2.706310 \cdot 10^{-3}+1.392383 \cdot 10^{-4} x_{2}+2.088575 \cdot 10^{-6} x_{2}^{2}-1.39238 \cdot 10^{-7} x_{2}^{3}, \\
& \Theta_{2}\left(x_{2}\right)=5.960916 \cdot 10^{-4}-2.045289 \cdot 10^{-5} x_{2}, \\
& z_{3}\left(x_{3}\right)=-1.244307 \cdot 10^{-3}+3.915627 \cdot 10^{-4} x_{3}-2.682863 \cdot 10^{-5} x_{3}^{2}-6.44622 \cdot 10^{-7} x_{3}^{3}, \\
& \Theta_{3}\left(x_{3}\right)=-1.392383 \cdot 10^{-4}+2.320639 \cdot 10^{-5} x_{3},
\end{aligned}
$$

where in $y_{i}\left(x_{i}\right)=0(i=1,2,3)$.

We now apply to the point $M_{2}$ the force $\boldsymbol{F}_{\mathbf{3}}\left(F_{3}=1 \kappa N\right)$ in the direction of the axis $q_{3}$. The deformed state of the frame caused by this force is shown in Fig. 4.

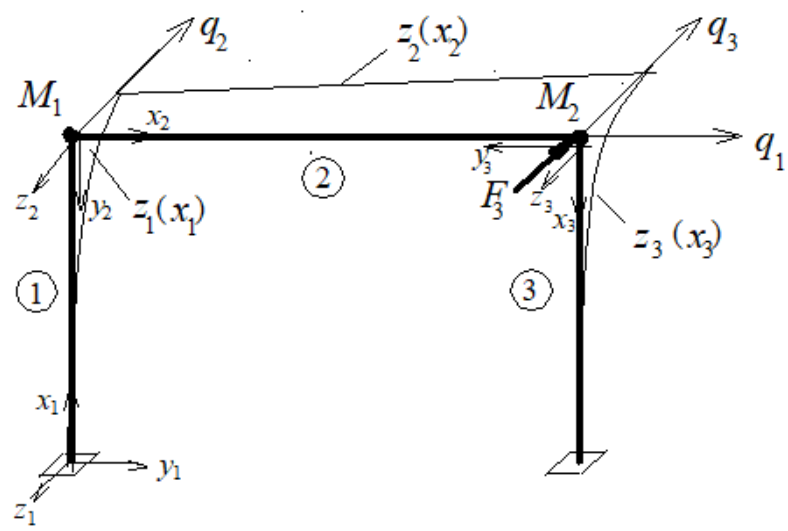

Fig. 4. Deformed state of the frame under the action of force $\boldsymbol{F}_{3}$

Analytical expressions of functions $z_{i}\left(x_{i}\right), \Theta_{i}\left(x_{i}\right)(i=1,2,3)$ :

$$
\begin{aligned}
& z_{1}\left(x_{1}\right)=-3.84318310^{-4} x_{1}+6.446219 \cdot 10^{-7} \cdot x_{1}^{3}, \Theta_{1}\left(x_{1}\right)=-2.320639010^{-5} x_{1}, \\
& z_{2}\left(x_{2}\right)=-1.244307 \cdot 10^{-3}-1.392383 \cdot 10^{-4} x_{2}-2.088575 \cdot 10^{-6} x_{2}^{2}+1.392383 \cdot 10^{-7} x_{2}^{3}, \\
& \Theta_{2}\left(x_{2}\right)=3.915627 \cdot 10^{-4}+2.045289 \cdot 10^{-5} x_{2}, \\
& z_{3}\left(x_{3}\right)=-2.706310 \cdot 10^{-3}+5.960916 \cdot 10^{-4} x_{3}+2.682863 \cdot 10^{-5} x_{3}^{2}-8.500325 \cdot 10^{-6} x_{3}^{3}, \\
& \Theta_{3}\left(x_{3}\right)=1.392383 \cdot 10^{-4}-2.320639 \cdot 10^{-5} x_{3}, y_{i}\left(x_{i}\right)=0(i=1,2,3) .
\end{aligned}
$$


Function components $F_{k}(s)(k=2,3)$ are presented as follows:

$\mathrm{F}_{k, 1}(s)=0$ at all $s$,

$\mathrm{F}_{k, 2}(s)=z_{1}(s), \mathrm{F}_{k, 3}(s)=\Theta_{1}(s)$ at $s \leq l_{1}$,

$\mathrm{F}_{k, 2}(s)=z_{2}\left(s-l_{1}\right), \mathrm{F}_{k, 3}(s)=\Theta_{2}\left(s-l_{1}\right)$ at $l_{1}<s \leq l_{1}+l_{2}$,

$\mathrm{F}_{k, 2}(s)=z_{3}\left(s-l_{1}-l_{2}\right), \mathrm{F}_{k, 3}(s)=\Theta_{3}\left(s-l_{1}-l_{2}\right)$ at $s>l_{1}+l_{2}$.

Next, we proceed to the definition of the elements of the matrices $\boldsymbol{F}, \boldsymbol{R}$ and $\boldsymbol{S}$, using formulas (8) and (16a). Solving equation (20), we find the frequencies of free vibrations of the frame with a system of weights loaded with longitudinal constant forces $P_{0, j}\left(P_{0, j}\right.$ are cargo weights $\left.M_{j}, j=1,2\right)$. Then, using (22), we construct the boundaries of the main regions of instability (Fig. 5).

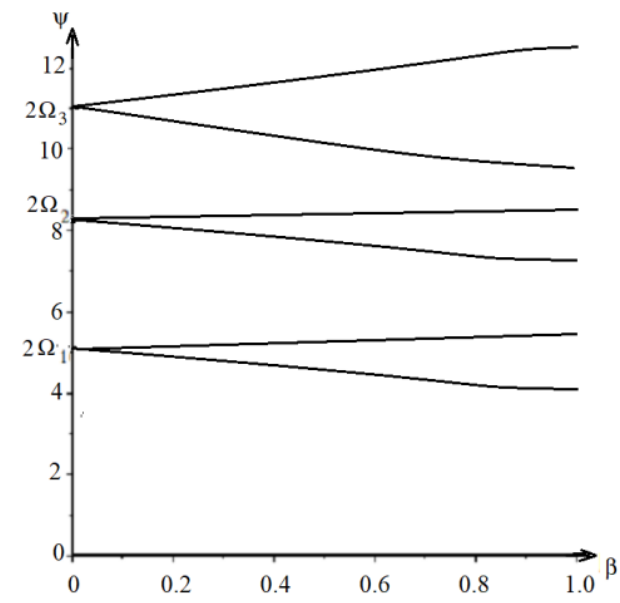

Fig. 5. Main areas of frame instability

Conclusions. The proposed method allows studying the dynamic stability of spatial multistory multi-span frame structures under seismic and dynamic operational influences, which must be done when designing structures for seismically dangerous regions $[9,10]$.

A dynamic model was also built taking into account the nonlinear properties of materials. This method allows you to make calculations with a small amount of accumulated error.

\section{References}

[1] E. Mettler, Biegeschwingung eneines Stabes unter pulsierender Axiallast. Mitt. Forsch., Anst. Gffii - Konzern, 1940.

[2] V.N. Celomey, Dinamicheskaya ustoychivoct elementov aviatsiannyh konstruksiy. Moskva, Aeroflot, 1939.

[3] V.V. Bolotin, Dinamicheskaya ustoychivost uprugikh sistem. M.: Gostekhizdat, 1956.

[4] N.A. Nikolaenko, Yu.P. Nazarov, Dinamicheskaya ysmostoykost soorugeniy. Moskva, Stroyizdat, 1988.

[5] V.F. Orobey, F.F. Chumak. "Ustoychivoct plockoy formi izgiba tonkostennyh sterghnevih system", Prikladnaya mehanika, v. 45 (55), no. 5, pp. 110-123, 2009.

[6] A.F. Daschenko, L.V. Kolomiyets, V.F. Orobey, N.G. Surianinov. Chislenno - analiticheskiy metod granichnyh elementov. Odessa, VMV, 2010.

[7] DBN V.1.1-12:2006. Zashchita ot opasnyh geologicheskih processov, vrednyh ekspluatacionnyh vliyanij, ot pozhara. Stroitel'stvo v sejsmicheskih rajonah Ukrainy; 2007-0102. K.: Minstroj Ukrainy, 2006.

[8] V.M. Fomin, Nelineyni dinamichni rozrahunki modely zalizobetonnyh karkasnih budivel I sporud z urahuvannym plastuchnosti materialiv: avtoref. dis. na zdobuttya nauk. stupenu d-ra tehn. nauk: 05.23.01, Odes'ka derzhavna akademiya budivnictva ta arhitekturi. Odesa, 2019.

[9] V.M. Fomin, I.P. Fomina, "Pobudova zon dinamichnoi nestiykosti dlya visotnih budivel u razi seismichnih diy", Mehanika ta matematichni metody, Tom II, Vip. 2, pp. 42-5, 2020. 
[10] V. Fomin, M. Bekirova, M. Surianinov, I. Fomina "Nonlinear dynamic analysis of a reinforced concrete frame by the boundary element method", Materials Science Forum, MSF 968, pp. 383-395, 2019.

[11] Y. Nakasone, S. Yoshimoto, T.A. Stolarski, Engineering analysis with ANSYS software, Oxford, Burlington, MA: Butterworth-Heinemann, 2006.

[12] E. Aulisa, A. Ibragimov, E.Y. Kaya-Cekin, "Fluid structure interaction problem with changing thickness beam and slightly compressible fluid", Discrete \& Continuous Dynamical Systems-S, pp. 1133-1148, 2014.

[13] G.Y. Baghdasaryan, M.A. Mikilyan, R.O. Saghoyan, "Influence of supersonic gas flow on the amplitude of non-linear oscillations of rectangular plates", MechanicsProceedings of National Academy of Sciences of Armenia, pp. 20-40, 2016.

[14] V.A. Kazakov, V.V. Gudenkov, K.V. Kazakov, V.P. Povarov, S.L. Vitkovskiy, Povishenie dinamicheskoy ustoychivosti energoblokov AES s reaktorom VVER-1000. Teploenergetika, T. 61, no. 1, pp. 47-53, 2014.

[15] EUR Presentations at the WNU International Forum on Harmonization of Reactor Design Requirements, Manchester (UK), September 1-4 2009. [Online]. Available: http://www.europeanutilityrequirements.org/Portals/0/Documents/EUR\%20Forum\%20W NU.zip.

[16] Methods to evaluate the dynamic stability of structures shake table tests and dynamic analyses. [Online]. Available: https://www.researchgate.net/publication/266267565.

[17] H. Smoljanović, I. Uzelac, B. Trogrlić, N. Živaljić, A. Munjiza, "A computationally efficient numerical model for a dynamic analysis of beam type structures based on the combined finite-discrete element method", Mater. Sci. Eng. Technol. 49 (5), pp. 651-665, 2018.

\title{
ДОСЛІДЖЕННЯ ПРОСТОРОВИХ ЗАДАЧ ДИНАМІЧНОЇ СТІЙКОСТІ ЗАЛІЗОБЕТОННИХ РАМ
}

\author{
${ }^{1}$ Фомін В.М., д.т.н, доцент, \\ Fomin@ogasa.org.ua, ORCID: 0000-0003-4814-6415 \\ ${ }^{1}$ Фоміна І.П., ст. викладач, \\ Fomina@ogasa.org.ua, ORCID: 0000-0001-7366-1537 \\ ${ }^{1}$ Одеська державна академія будівництва та архітектури \\ вул. Дідріхсона, 4, м. Одеса, 65029, Україна
}

\begin{abstract}
Анотація. У статті запропоновано метод побудови областей динамічної нестійкості залізобетонних рам в просторі параметрів (частота і амплітуда) сейсмічних і експлуатаційних динамічних впливів, що викликають появу в стержнях конструкцій поздовжніх сил, які періодично змінюються в часі і призводять при значеннях цих параметрів з областей нестійкості до необмеженого росту амплітуд поперечних коливань. Запропонований метод продемонстровано на конкретному прикладі, в якому розглядається просторова задача динамічної стійкості Пподібної рами з розташованими на ній двома зосередженими масами, які знаходяться під дією вертикальних періодичних сил. Ці сили створюють в вертикальних стержнях рами періодичні в часі поздовжні сили. Проведено побудову областей динамічної нестійкості рами.

3 погляду людської діяльності коливання можуть бути як корисними, так і шкідливими. Ми можемо спостерігати коливання різних будівель, споруд, мостів, які викликають додаткову напругу та деформацію цих споруд, надають шкідливий вплив на їх безпечне функціонування. Занадто інтенсивні коливання призводять до серйозних наслідків. Це призводить до руйнування окремих елементів споруди та, як наслідок, до аварій. Найбільш руйнівна дія коливань спостерігається при землетрусах та вибухах. Вивчення параметрів коливань має важливе практичне значення. Це дозволяє уникнути небажаних наслідків шляхом обмеження впливу коливань. Тільки на базі досконалого вивчення різних видів коливань можна вирішити важливі практичні проблеми динаміки споруд. Розв'язання задач динаміки є складною
\end{abstract}


проблемою. На відміну від статичного розрахунку, щодо коливань доводиться враховувати додатковий чинник - час. Динамічний розрахунок споруд забезпечує їх несучу здатність при спільній дії статичних та динамічних навантажень. Конструкцію розглядатимемо, як систему з розподіленим за нею нескінченним числом елементарних мас 3 нескінченно великим числом динамічних ступенів свободи.

Ключові слова: залізобетонні рами, динамічна нестійкість, області нестійкості.

\title{
ИССЛЕДОВАНИЕ ПРОСТРАНСТВЕННЫХ ЗАДАЧ ДИНАМИЧЕСКОЙ УСТОЙЧИВОСТИ ЖЕЛЕЗОБЕТОННЫХ РАМ
}

\author{
${ }_{1}^{1}$ Фомин В. М., д.Т.н, доцент, \\ Fomin@ogasa.org.ua, ORCID: 0000-0003-4814-6415 \\ Фомина И.П., ст. преподаватель, \\ Fomina@ogasa.org.ua, ORCID: 0000-0001-7366-1537 \\ ${ }^{1}$ Одесская государственная академия строительства и архитектуры \\ ул. Дидрихсона, 4, г. Одесса, 65029, Украина
}

\begin{abstract}
Аннотация. В статье предложен метод построения областей динамической неустойчивости железобетонных рам в пространстве параметров (частота и амплитуда) сейсмических и эксплуатационных динамических воздействий, вызывающих возникновение в стержнях конструкций продольных сил, которые периодически меняются во времени и приводят при значениях этих параметров из областей неустойчивости к неограниченному росту амплитуд поперечных колебаний. Предлагаемый метод продемонстрирован на конкретном примере, в котором рассматривается пространственная задача динамической устойчивости П-образной рамы с расположенными на ней двумя сосредоточенными массами, которые находятся под действием вертикальных периодических сил. Эти силы создают в вертикальных стержнях рамы периодические во времени продольные силы. Проведено построение областей динамической неустойчивости рамы.

С точки зрения человеческой деятельности колебания могут быть и полезными, и вредными. Мы можем наблюдать колебания различных зданий, сооружений, мостов, которые вызывают дополнительные напряжения и деформации этих сооружений, оказывают вредное воздействие на их безопасное функционирование. Слишком интенсивные колебания приводят к серьезным последствиям. Это приводит к разрушению отдельных элементов сооружения и, как следствие, к авариям. Наиболее разрушительное действие колебаний наблюдается при землетрясениях и взрывах. Изучение колебаний имеет важное практическое значение. Это позволяет избежать нежелательных последствий колебаний путем ограничения их уровня. Лишь на базе глубокого изучения различных видов колебаний можно решить важные практические проблемы динамики сооружений. Решение задач динамики представляет собой сложную проблему. В отличие от статического расчета, при изучении колебаний приходится учитывать дополнительный фактор - время.

Динамический расчет сооружений обеспечивает их несущей способностью при совместном действии статических и динамических нагрузок. Констукцию будем рассматривать как систему с распределенным по ней бесконечным числом элементарных масс с бесконечно большим числом динамических степеней свободы.

Ключевые слова: железобетонные рамы, динамическая неустойчивость, области неустойчивости.
\end{abstract}

Стаття надійшла до редакції 20.10.2021 